\title{
A COMPREHENSIVE STUDY OF FAMILY PLANNING AMONG MUSLIMS OF ASSAM
}

\author{
Ilias Ali ${ }^{1}$
}

1 Professor, Department of Surgery, HOD Emergency Medicine, Gauhati Medical College.

\section{ABSTRACT}

\section{BACKGROUND}

There is a prevailing perception that family planning is a red flag in Islam and it is deviant from the teachings of the Quran and the Hadith. In Assam family planning among Muslim particularly, among the non-indigenous Muslim, the inhabitant of riverine areas was quite unpopular. They are usually poor, uneducated and various types of misconceptions widely prevalent among them. Following extensive awareness programme using different verses from the Quran and the Hadith, the Muslims of Assam have started participating in birth control programme. Now, family planning is no more a myth among Muslims of Assam.

\section{KEYWORDS}

Family Planning, the Quran and the Hadith, Muslim of Assam, Religious Misconception.

HOW TO CITE THIS ARTICLE: Ali I. A comprehensive study of family planning among Muslims of Assam. J. Evolution Med. Dent. Sci. 2017;6(4):347-349, DOI: 10.14260/Jemds/2017/78

\section{BACKGROUND}

There is a prevailing perception that family planning is a red flag in Islam. That Muslims are firmly against the adoption of family planning measures is a popular misconception. There is a general impression that family planning is deviant from the teachings of the Quran and the Hadith. And that Muslims are fast multiplying and one day they will outgrow the majority community. Justice Rajinder Sachar's report on the Muslim community in India demolishes such popular bigotry. ${ }^{1}$ In his report, he stated that there is substantial demand from the community for fertility regulation and for modern contraceptives and at least one-third of the Muslim couples have already used contraceptive. ${ }^{2}$ My own experience while working among the Muslims of Assam for the last 8 years corroborates Justice Sachar's findings that Muslims are not averse to partaking in family planning schemes.

There is no controversy among the population experts that poverty, illiteracy, insecurity and inaccessibility to birth control programmes are the root causes for the rampant population growth in the downtrodden sections of the community irrespective of cast and religion of our country. Unfortunately, we tend to gloss over this fact and pin the blame on the Muslim clergy for the swelling demography in areas populated by such Muslims. We also need to bear in mind that among the Muslims at the bottom-end of the social pyramid; illiteracy, underage marriage, polygamy, poverty and population outburst are not only pervasive but are also interrelated, which only compounds the problem of burgeoning birth rates.

If overall development of the marginalised Muslims remain elusive, then all efforts directed towards curbing population growth will go in vain. Among such Muslims, religious dogmas and social taboos are deeply entrenched.

Financial or Other, Competing Interest: None.

Submission 24-10-2016, Peer Review 01-01-2017,

Acceptance 06-01-2017, Published 12-01-2017.

Corresponding Author:

Dr. Ilias Ali,

House No. 31

C/o. Global Hospital,

Hatigaon-Sijubari, Dispur-781038,

Guwahati, Assam, India.

E-mail: drilias.ali76@gmail.com

DOI: $10.14260 /$ jemds $/ 2017 / 78$
Contrary to my expectations, the enthusiasm, co-operation and appreciation that our family planning camps received in those pockets of high population densities was simply phenomenal. Shedding religious inhibitions, people from conservative backgrounds flocked to our camps in droves. During my field trips, most of the clerics that I have exchanged views with were not averse to the concept of family planning and have certainly not tagged our work as blasphemous. But it is equally true that distorted religious beliefs and traditions are largely prevalent among the non-indigenous Muslims of riverine areas. The thinking and talking heads of this particular group are mistaken in prejudging that family planning is nothing but sterilisation. Most of them are even averse to discussing issues of birth control in the light of Islamic teachings. They need to concur with the fact that Islam calls for a knowledge-based society.

Among the Muslims of Assam's riverine areas, there is an unusually high demographic growth. This is hanging like a Damocles' sword in their path to upward mobility. In such a backdrop, the chances for their socio-economic progress are rather slim. Nonetheless, it has dawned on many within the community that only a family with fewer children can be helpful in ushering into a life of prosperity and security. For this reason, many have come forward to attend our family planning camps and have responded with fervour to our call for family limitation. During the course of our on-going campaign, countless couples have expressed that they are not in favour of raising large families as many mouths to feed implies untold hardships and miseries. Those who bear several children were often borne unintentionally. It needs to be stressed that it is not because of the lack of participation by Muslims in family planning programmes that such large families have cropped up in the riverine areas, but due to the dearth of such facilities. During my various trips to the riverine areas in account of the family planning campaign I was witness to the fact that there is a near total lack of logistics for family planning services in almost all the areas I covered. My own finding has also been reflected in the Justice Sachar Committee report.

Teeming multitudes of underfed, half-clad and uneducated souls cannot be the essence of a true Islamic society. Even an otherwise religious person with several children will find it difficult in abiding by the righteous ways of life as per the strictly laid down instructions of the Holy Quran. Allah, the 
Exalted does not call on his followers to overburden themselves by raising large families simply for material gains, as this could be harmful to their children. The Holy Quran forbids believers from raising large untenable families. ${ }^{3}$ Incidentally, at the dawn of Islam, the Prophet himself had not opposed the methods of birth control practiced in those days known as 'Azl' (coitus interruptus or withdrawal). 4

Several nations in the Islamic world have achieved remarkable success in birth control. As against India's fertility rate of 2.6 Iran's rate is 1.88, while that of Indonesia is 2.2 (CIA Fact Book, 2009). The main reason behind this is the broadbased development of these countries. The respective governments, i.e. Indonesia ${ }^{5}$ and Iran $^{6}$ have implemented family planning schemes in a scientific manner and it is noteworthy that the clergy has come out in open support of such policies. There are shining examples of religious heads campaigning for the robust execution of such programmes. It bears recalling that Ayatollah Khomeini had once issued a religious edict that if a couple has 2 children and is struggling against odds in raising them, then they are bound by the Shariat to adopt family planning methods. The Vilayat-e-Fiqh (Council of Islamic Jurisprudence) of Iran was in sync with the Ayatollah and the Ulema was in the vanguard of the noble mission of spreading the message of population control. Iran was the first nation to launch a programme of permanent sterilization of both genders. Iran is also the only country in the world where it is incumbent upon all seeking to enter into wedlock, to undergo counselling in family planning to be entitled for marriage registration. Such a showcase achievement of birth control has set a precedent in the Muslim world, which is increasingly becoming worthy of emulation by the rest. ${ }^{6}$ Infant and maternal mortality rates have drastically dropped in Iran, while the social status of women has grown manifold.

In India, states like Kerala which has witnessed credible all-round development, the fertility rate among the Muslim brethren is lower than that of their Muslim counterparts of other states. Similar trends are noticeable in the neighbouring state of Tamil Nadu. This shows that with growth and development, society is better placed in curbing population growth. It is heartening to recall the overwhelming participation of Muslims in our family planning camps and in keeping with the spirit of public participation; it is incumbent upon us to bridge the gap in meeting the growing demand for family planning. In a random study of 2456 participants in male sterilisation procedure in 2009-10 in Assam, 1390 (55.37\%) were Hindus, while 1066 (43.40\%) were Muslims. Another study of 2383 people who underwent permanent sterilisation procedure in Barpeta district of Assam in the year 2011-12 of which 996 were Hindus (41.2\%), while 1387 (58.8\%) people of the group were Muslims. And it bears reiteration that of Assam's population; Muslims constitute $34.22 \%$ (as per census report 2011).

Overwhelming Participation of Muslim Community in Male Sterilisation (NSV): 2009 - 2010

\begin{tabular}{|c|c|c|c|c|}
\hline $\begin{array}{c}\text { Date of NSV } \\
\text { CAMP }\end{array}$ & Place & Total No. & Other Community & Muslim \\
\hline 27.6 .09 & Garoimari, Kamrup & 23 & 0 & 23 \\
\hline 2.07 .09 & Kachua, Nagaon & 36 & 02 & 92 \\
\hline $\begin{array}{c}3.07 .09 \\
8.07 .09\end{array}$ & Pachmail, Sonitpur & 98 & 06 & 39 \\
\hline 15.7 .09 & Sonai, Cachar & 41 & 02 & 48 \\
\hline 10.8 .09 & Dagaon, Nagaon & 48 & 0 & \\
\hline
\end{tabular}

B. Beneficiaries (Male and Female) who Adopted Permanent Procedure (NSV and Tubectomy):

\begin{tabular}{|c|c|c|c|c|}
\hline $\begin{array}{c}\text { Period when } \\
\text { Procedure } \\
\text { Performed }\end{array}$ & District & $\begin{array}{c}\text { Total No. Beneficiary } \\
\text { (Male and Female) } \\
\text { Adopted Permanent } \\
\text { Procedure }\end{array}$ & Other Community & Muslim \\
\hline $\begin{array}{c}\text { 11.07. } 2016 \\
\text { To } \\
30.07 .2016\end{array}$ & Barpeta & 430 & 208 & $222(51.62 \%)$ \\
\hline DO & Hilakandi & 345 & $67(19.42 \%)$. & $278(80.57 \%)$ \\
\hline
\end{tabular}

Being a Muslim family planning activist, I do sincerely believe that conquering of myth, misbelief and misconception prevalent in the Muslim society against family planning is not an insurmountable task. Therefore, we need to carry out our activities on a larger scale, so as to cover the widest possible area and in this regard we implore the Government of India to redouble its efforts in widening the scope of family planning initiative amongst the Muslim masses.

\section{REFERENCES}

[1] https://www.quora.com/Why-dont-Muslims-realizethe-value-of-family-planning-What-do-educatedMuslims-feel-about-this 
[2] http://www.goole.co.in/amp/s/hawkeyeindia.wordpres s.com/2006/12/06/the-muslim-demography-of-indiasacher-commitee-report/amp/?client=safary

[3] http://www.prb.org/pdf04/islamfamilyplanning.pdf

[4] https://www.answeringislam.org/Muhammad/Inconsistent/azl.html
[5] https://www.guttmacher.org/journals/ipsrh/2004/03/ political-management-indonesian-family-planningprogram

[6] https://www.theglobalist.com/iran-a-model-for-famillyplanning/ 